\title{
Determinants of Potential Output Growth: Empirical Evidence in 18 OECD Countries, 1990-2016
}

\author{
MANSOKKU LEE \\ State University of New York \\ Geneseo, NY, U.S.A
}

\begin{abstract}
In this paper, we examine the contribution of labor quantity, labor quality, ICT capital, non-ICT capital, and the productivity of production system to potential output growth for 18 OECD countries from 1990 to 2016. For this, we develop a measure of a country's potential output growth using a timeseries analysis and apply panel data regressions to find empirical evidence. Empirical findings suggest that in developed countries, improvements in productivity and labor quality are major determinants that lead to an increase in economic potential.
\end{abstract}

Keywords: potential output growth, Kalman filter, panel data regressions, productivity, labor quality

\section{INTRODUCTION}

Economic growth can be defined as an increase in output (goods and services) production, and gross domestic product (GDP) is a popular measure of the value of output produced. The realization of economic growth is the primary goal of every government because it enhances the standard of living by raising income levels and reducing poverty. Since GDP per capita is the best measure of prosperity and national competitiveness available across all

\footnotetext{
Assistant professor. School of Business, 1 College Circle, South Hall 100, State University of New York, Geneseo, NY 14454, USA; Phone: +1 585-245-5363; e-mail: leem@geneseo.edu
} 
countries, it is an important component of Business Competitiveness Index (BCI) (Porter, Ketels, and Delgado 2007).

A nation's revealed economic growth is measured in actual GDP growth, which is based on both its potential output growth and various random shocks to the economy. Theoretically, in the absence of shocks, the economy is expected to achieve its potential level of output. However, various random shocks cause the economy to produce more or less than its potential level, creating the shortrun business cycles fluctuations. Thus, a country's actual GDP growth rates deviate from its potential rates of output growth. Porter, Ketels, and Delgado (2007) point out that GDP per capita can be changed by various factors, such as macroeconomic shifts, political developments, resource price swings, and spurts of foreign investment, and therefore they argue that the productive potential of a nation's economy is the only reliable source of true prosperity.

While actual GDP indicates the value of realized outputs, a nation's potential output represents more fundamental aspects of the economic system. The estimate of economic potential is referred to as potential or trend GDP. Since potential GDP is unobservable, its estimation depends on statistical methods and thus requires understanding of the structural effects of factors of production, such as labor, capital, and productivity, on a nation's production system. It is worth to study the determination of potential GDP because identifying the fundamental relationship between production inputs and outputs allows the efficient resource allocation of the economic system.

From this perspective, the goal of this paper is twofold: (i) developing a measure of a country's potential GDP growth and (ii) examining how various determinants have influenced potential GDP growth in advanced economies over the past three decades. For empirical analysis, we construct a panel data regression model for developed countries. Since the 1990s, there have been extensive investments in information and communication technologies (ICT) industries. In addition, the adoption of new technologies has increased the demand for skilled and educated workers (Goldin and Katz 2009). This paper incorporates such industrial trends into empirical specifications by separating labor input into two components, labor quantity and labor quality, and capital input into ICT and non-ICT capital, and examining their impacts, whereas many other studies discuss the overall influence of labor and capital 
inputs used in production without such separation. Our empirical findings suggest that in developed economies, productivity and labor quality are major determinants that lead to an increase in potential output growth. Especially, the contribution of these two determinants is significantly large in G-7 countries compared to other developed countries. We also find that over the past three decades, ICT has spurred potential GDP growth in most of the developed countries, and find that the contribution of non-ICT capital has been significant only in G-7 countries.

Much of the literature has regarded potential GDP growth as constant, disregarding structural changes in the production system. For a data-oriented empirical approach, this paper proposes a structural time-series model and then extract timevarying potential GDP growth from actual GDP growth by applying econometric techniques to the model. It is important to estimate potential GDP because it represents an economy's long-run level of output production and as a consequence, long-term industrial and economic policies aim to increase potential output growth. As an indicator of business cycle conditions, it also provides short-term policy goals for stabilizing and reinvigorating the economy, such as a target inflation rate. At a firm or industry level, potential GDP growth is an important consideration as it gives information on future domestic consumption and market potential. Especially, in building international business strategies, together with predicting the future business cycle, the forecast of potential GDP is a major concern because it can determine the level of inward foreign direct investment (FDI).

This paper contributes to the literature by examining the influence of the long-run growth of labor, capital, and productivity on potential GDP while many empirical studies focus on examining the contribution of the amount of production inputs on a country's economic growth measured in actual GDP rather than its potential output.

The remainder of this paper is organized as follows. Section THEORETICAL FRAMEWORK reviews relevant studies and a theoretical model. In section MEASURING POTENTIAL OUTPUT GROWTH, we estimate the growth rate of potential output using statistical methods. Section REGRESSION ANALYSYS presents the regression model, variable description, and preliminary data analysis. Section EMPIRICAL RESULTS reports regression results, 
and the last section includes concluding remarks.

\section{THEORETICAL FRAMEWORK}

This section presents the definition of potential GDP growth and describes its determinants. If $y_{t}$ denotes the level of output at time $t$, then the growth rate of GDP at time $t$ can be given by the log difference of the two consecutive periods' actual GDP:

$$
\text { GDP growth } \text { gr }_{t} \ln \left(Y_{t}\right)-\ln \left(Y_{t-1}\right)
$$

The potential GDP (or trend GDP) is an expected level of maximum output that an economy can achieve at the level of full employment without causing any inflation. If $Y_{t}^{*}$ denotes potential GDP, its growth rate (natural rate of output growth) can be given by

$$
\text { Potential GDP Growth } \text { }_{t} \ln \left(Y_{t}^{*}\right)-\ln \left(Y_{t-1}^{*}\right)
$$

If potential GDP increases at a constant rate over time, the growth rate is deterministic. By differentiating underlying assumptions on potential GDP, we can construct the model of stochastic potential GDP growth. A detailed model setup is available in the next section. The difference between the log real GDP and the log potential GDP at time period $t$ is referred to as output gap.

$$
\text { Output Gap }=\ln \left(Y_{t}\right)-\ln \left(Y_{t}^{*}\right)
$$

The output gap serves as a proxy for business cycle, expressed as a percent of potential GDP. A positive output gap indicates a boom whereas a negative output gap represents a recession.

Solow (1957)'s growth accounting provides the measures of the contribution of factors of production to economic growth. Consider the following Cobb-Douglas production function that exhibits the determination of the level of output:

$$
Y=A K^{\alpha} L^{1-\alpha}
$$

where $Y$ is the aggregate level of output (GDP), the coefficient $A$ represents the level of technology, $K$ is capital stock, $L$ is labor 
stock, and $\alpha$ indicates the share of capital. This production system assumes constant returns to scale since $\alpha+(1-\alpha)=1$. By taking log on both sides of the model, we show that changes in output production can be explained by a linear combination of factors of production.

$$
\ln Y=\ln A+\alpha \ln K+(1-\alpha) \ln L
$$

Both labor and capital stocks are main determinants of output growth. This analysis indirectly calculates the rate of technological advance, measured as a residual. The changes in output not directly caused by changes in labor and capital inputs can be accounted for by changes in $A$, which is referred to as Total Factor Productivity (TFP). TFP represents the economy's level of productivity that is determined by technological progress.

Since potential output growth is a key element of a country's sustainable economic growth and competitiveness, there has been efforts to find its determinants. Earlier works focus on labor growth and capital accumulation as main determinants of economic growth in relation to a potential level of output growth (e.g., Solow 1957; Swan 1956). They recognize that prosperity is determined by the productivity of economy (TFP) that is fueled by technological advances. While early studies take technological progress as exogenously given, a group of researchers regard it as an outcome of endogenous process, dependent on the size of human capital in research and development (R\&D) areas (Jones 1995; Lucas 1988; Romer 1990). Especially, Romer (1994) and Aghion and Howitt (1998) suggest that commercially oriented innovation efforts can encourage technological progress and the growth of productivity. Porter (1990) argues that the determinants of productivity differ by the degree of economic development. In an investment-driven economy, the efficiency of production system is the main source of productivity improvement. Therefore, it is important to invest in efficient infrastructure, business-friendly public sector, incentive systems for investment, and better utilization of investment capital. In a more evolved economic system, an innovation-driven economy, the ability to produce innovative goods and services using cuttingedge methods is the main element of competitiveness, which is the underpinning of sustainable national wealth and prosperity. Since Griliches and Lichtenberg (1984) have suggested the positive 
impact of R\&D capital on TFP growth, many studies have provided empirical evidence on the relationship between R\&D activities and productivity (e.g., Coe and Helpman 1995; Coe and Hoffmeister 2009; Griliches 1998; Guellec and Van Pottelsberghe De La Potterie 2004). Some papers argue that entrepreneurship is a bridge that connects $R \& D$ activities to innovation and thus contributes to output production (Audretsch and Keilbach 2004; Michelacci 2003). Vandenbussche, Aghion and Méghir (2006)'s study on TFP determinants in OECD countries suggests that high-skilled human capital positively influences the growth of TFP. Studies on the contribution of human capital highlight the role of job training and higher education and argue that both the quantity and quality of workforce have a positive influence on economic prosperity (Gennaioli et al. 2012; Krueger and Lindahl 2001).

As a more comprehensive approach to understanding the origin of national prosperity, Delgado et al. (2012) examine the contribution of the three drivers of foundational competitiveness: social infrastructure and political institutions, monetary and fiscal policy, and microeconomic conditions. Especially, quality of national business environment, state of cluster development, and sophistication of company operations and strategy are main determinants of microeconomic environment. For a measure of competitiveness, Delgado et al. (2012) use the productivity of potential worker, which is defined as the expected level of output per working-age individual. Their empirical study that covers more than 130 countries over the period of 2001-2008 suggests that there are positive and significant influences of the three drivers on the measure of national competitiveness.

\section{MEASURING POTENTIAL OUTPUT GROWTH}

In this section, we provide a measure of potential output by applying a time-series filtering technique. As a first step, following Watson (1986) and Clark (1989), we construct a univariate unobservable-component model. Suppose that a time series $y_{t}$, actual GDP growth can be decomposed into a trend component $\tau_{t}$ and a cyclical component $c_{t}$ as follows:

$$
y_{t}=\tau_{\mathrm{t}}+c_{t} \quad t=1,2,3, \ldots, T
$$


The smoothed trend GDP represents economy's long-run level of output growth, and can be defined by

$$
\tau_{t}=\beta_{t-1}+\tau_{t-1}+v_{t}, \quad v_{t} \sim \text { i.i.d.N } N\left(0, \sigma_{v}^{2}\right)
$$

In equation (2), the trend is assumed to follow a random walk process, with drift $\beta_{t-1}$. In this model, the drift $\beta_{t}$ is the random rate of change and assumed to follow a random walk as well:

$$
\beta_{t}=\beta_{t-1}+\omega_{t}, \quad \omega_{t} \sim \text { i.i.d.N }\left(0, \sigma_{\omega}^{2}\right)
$$

Finally, we close the model by assuming that the output gap follows a second order autoregressive process, as Clark (1987) and Harvey (1991) suggest:

$$
c_{t}=\phi_{1} c_{t-1}+\phi_{2} c_{t-2}+\varepsilon_{t}, \quad \varepsilon_{t} \sim \text { i.i.d.N }\left(0, \sigma_{\varepsilon}^{2}\right)
$$

The trend component $\tau_{t}$ moves smoothly as only if the variance of error term $\sigma_{v}^{2}$ is smaller than the variance of cyclical component $\sigma_{\varepsilon}^{2}$. The variance of the error of drift $\sigma_{\omega}^{2}$ is also assumed to be smaller than $\sigma_{\varepsilon}^{2}$. We set $\sigma_{\omega}^{2}$ to be positive and $\sigma_{v}^{2}$ to zero for a smoother trend with stochastic drift suggested by Harvey and Streibel (1998), Harvey (2001), Harvey and Bernstein (2003), and Harvey et al. (2004). As a result, shocks to the rate of drift (potential output growth) captured by $\sigma_{\omega}^{2}$ are only innovations to potential output.

Watson (1986) originally assumes that the rate of potential output growth is constant over the sample period by setting $\sigma_{\omega}^{2}=0$. However, some studies, such as Clark (1989) and Perron and Wada (2009), suggest that the use of stochastic slope can avoid potential misleading results and better explains the data. Assuming a variable potential growth rate for the trend component is a testable hypothesis, and many studies support this set-up by showing empirical results. Gerlach and Smets (1997) point out that such an assumption on a deterministic rate of output growth is restrictive to apply to many industrialized economies and suggest allowing the rate of drift to vary over time. Harvey and Streibel (1998) and Harvey (2001) propose to test the null of $\sigma_{\omega}^{2}=0$ to confirm empirically the random walk assumption. Harvey et al. (2004) also apply a Lagrange Multiplier (LM) test on the same null hypothesis against the alternative, $\sigma_{\omega}^{2}>0$. The test rejects the null of a deterministic trend 

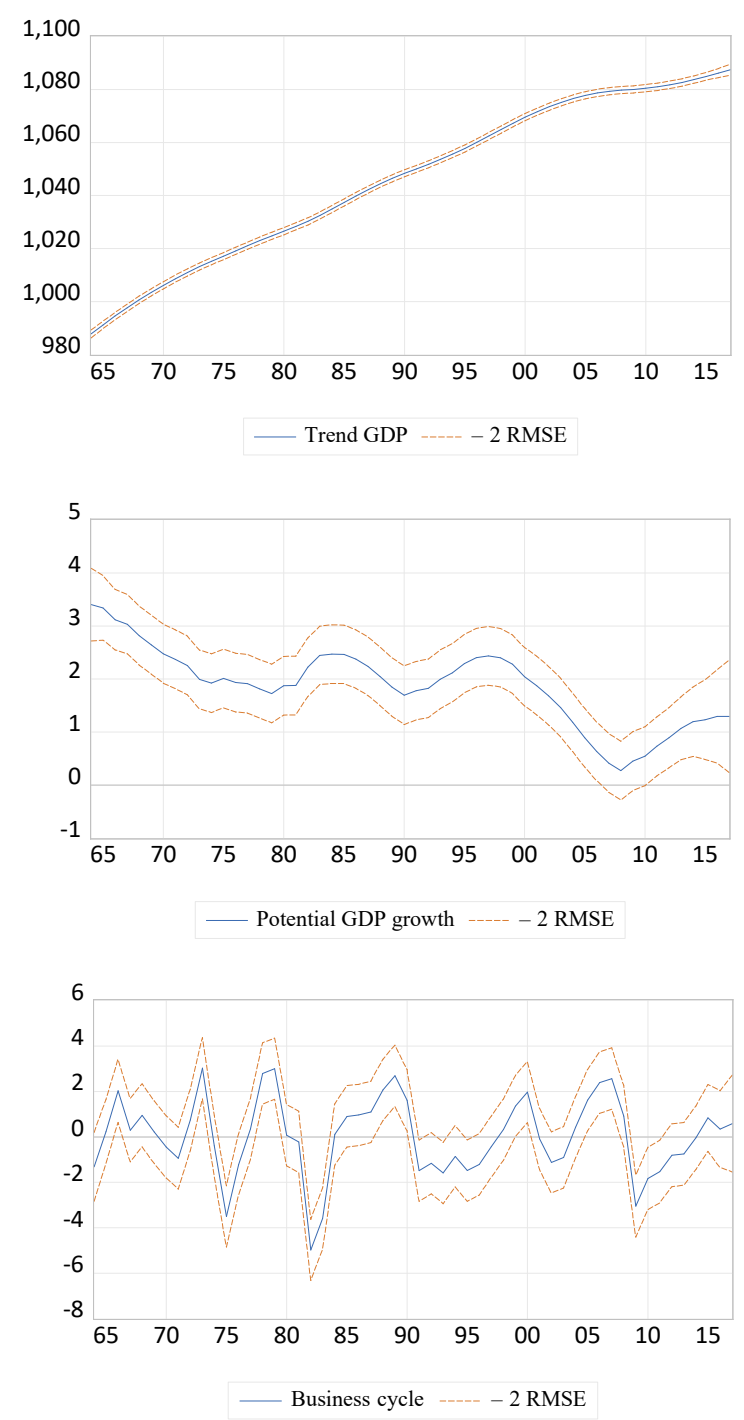

Figure 1. Estimates of Trend GDP, Potential GDP Growth, and Output Gap in the U.S.

as well.

The goal of our empirical strategy is to have estimates of unobservable components: the trend, output gap, and potential rate of output growth. For this purpose, we convert the model into the form of State-Space representation and then apply the Kalman filter 
Australia

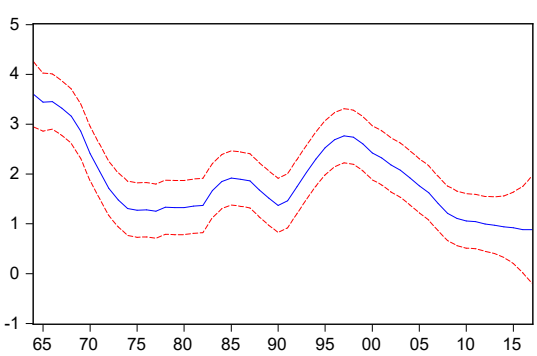

— BETA ------2 RMSE

Belgium

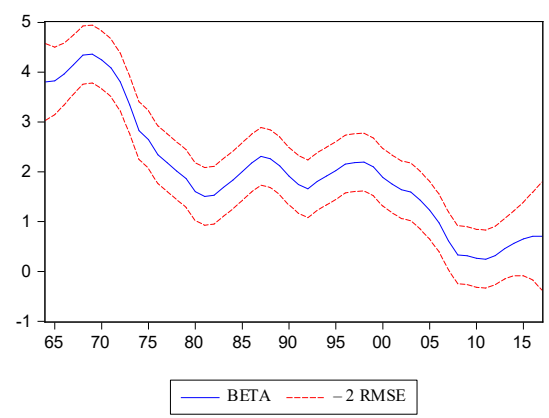

Denmark

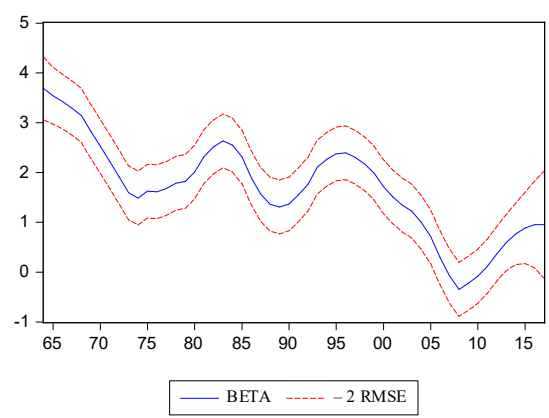

Austria

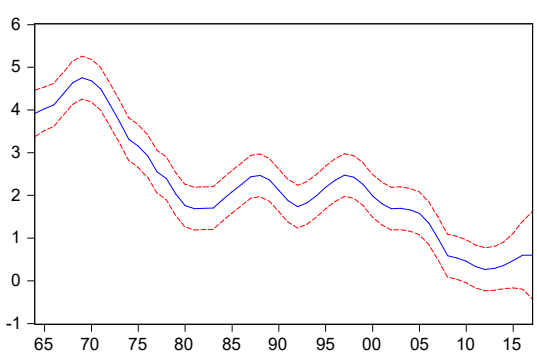

— BETA --.- -2 RMSE

Canada

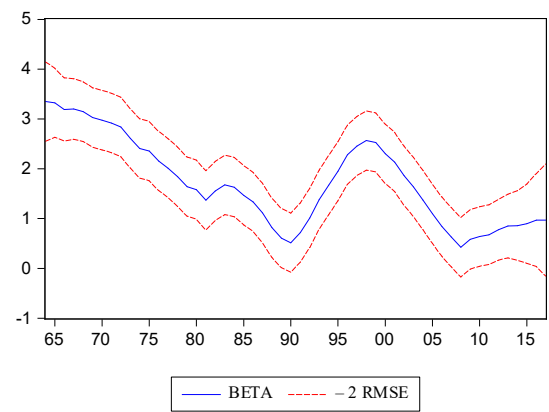

Finland

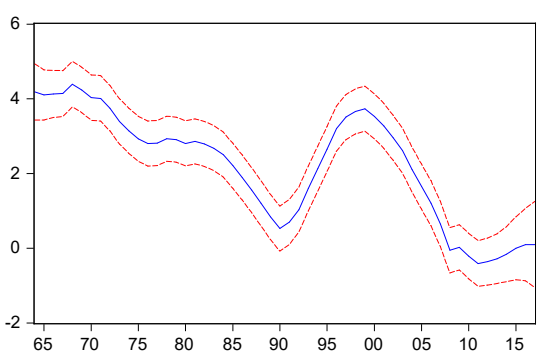

_ BETA --.- -2 RMSE

Figure 2. Potential GDP Growth (Beta)

to estimate parameters in equations (1) through (4) simultaneously. The appendix describes details on the Kalman filtering process. We use the World Bank's GDP per capita series for 18 OECD countries for the period of 1960-2017.

Figure 1 presents the estimates of the three components of the U.S. 

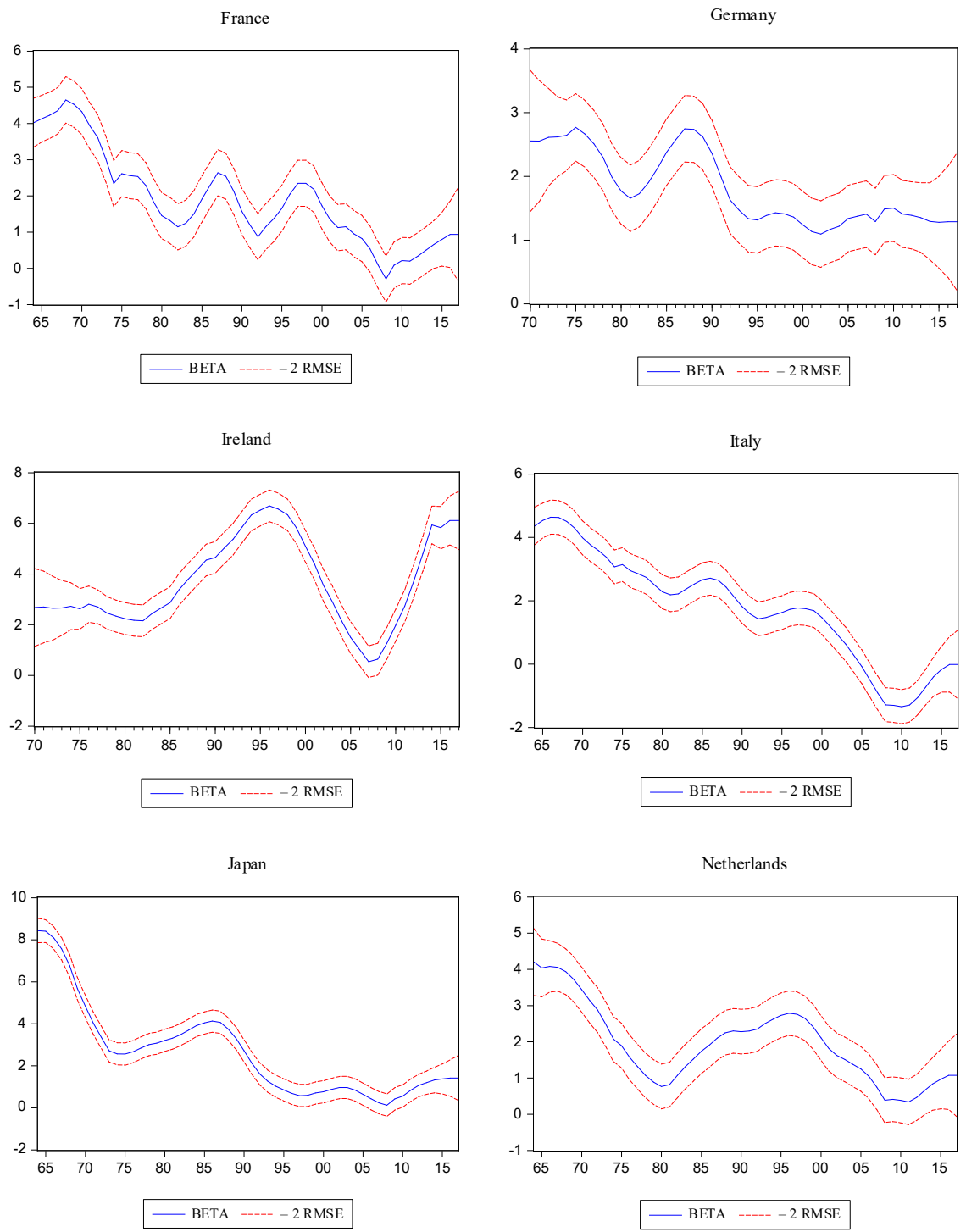

Figure 2 (continued). Potential GDP Growth (Beta)

GDP as examples. In figure 1, trend GDP is given by $100 \cdot \ln$ GDP per capita. In the above model, the stochastic drift $\left(\beta_{t}\right)$ can serve as the growth rate of potential GDP. Figure 1 show that in the U.S., potential GDP growth has declined over the past decades.

Figure 2 presents estimates of potential growth rates, which is the 
Norway

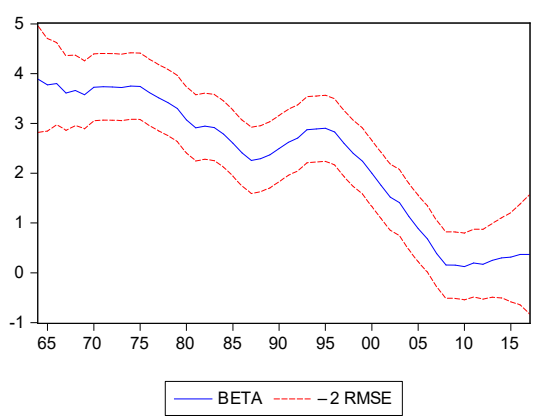

Sweden

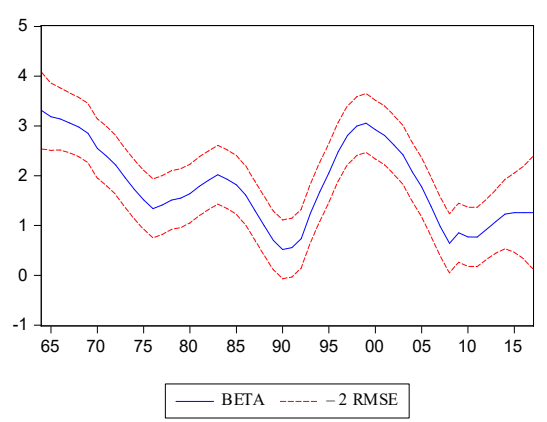

UK

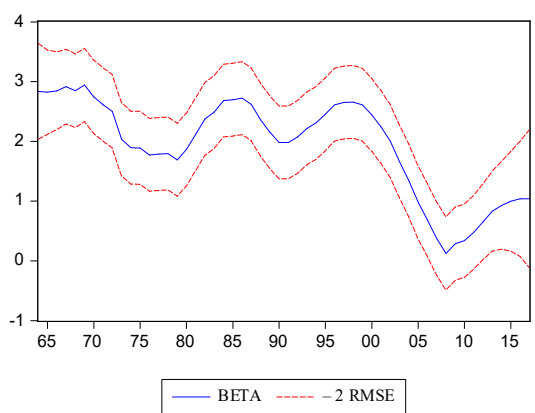

New Zealand

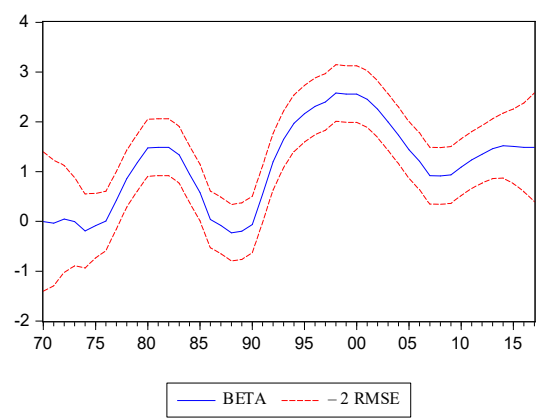

Switzerland

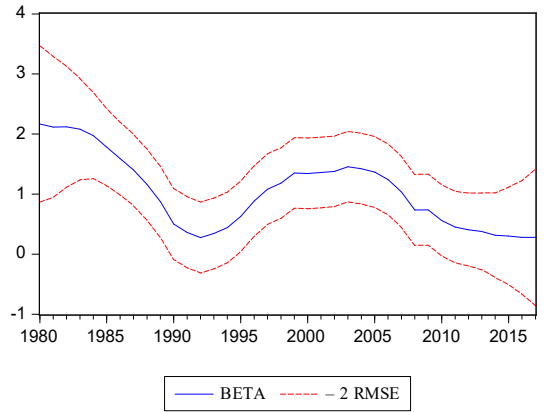

US

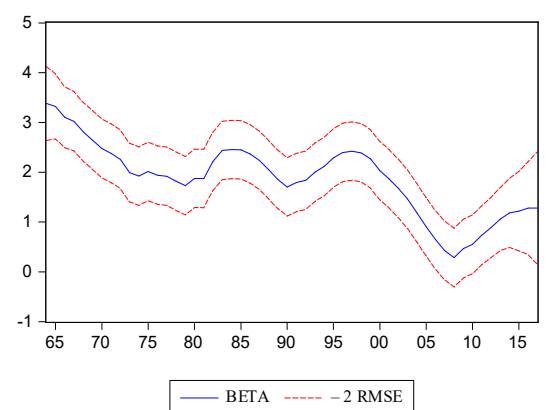

Figure 2 (continued). Potential GDP Growth (Beta)

beta $\left(\beta_{t}\right)$ in equation (3), for sample developed countries. Most sample countries experienced economic advancement and industrialization prior to the 1970s and gradual decline until the mid-1990s. Countries, such as Canada, Finland, Ireland, Netherlands, and Sweden experienced an increase in potential growth in the 1990s. It 
is common for many of countries to have increased potential output growth after 2008-2009 global financial crisis.

\section{REGRESSION ANALYSIS}

To examine the contribution of underlying factors of production to potential GDP growth, we propose the following panel data regression model:

$$
\begin{aligned}
& \text { Potential GDP Growth } \text { Git }=\alpha+\beta T F P_{i t}+L_{i t}^{\prime} \gamma+K_{i t}^{\prime} \zeta+\phi_{t}+\eta_{i}+\varepsilon_{i t} \\
& i=1, \ldots, 18 . \quad t=1990, \ldots, 2016 .
\end{aligned}
$$

where TFP is total factor productivity, $L$ is a regression vector that contains two variables, labor quality and labor quality, and $K$ is a regression vector that includes two variables, ICT and Non-ICT capital. Estimates for potential GDP growth $\left(\beta_{t}\right)$ is a dependent variable. Since the dependent variable, potential GDP growth, is an estimate of annual growth rate of long-run trend GDP, the corresponding regressors are also measured in percentage changes of annual trend (the long-run level). For this, we apply filtering techniques again to annual growth of labor quantity, labor quality, ICT, non-ICT capital, and TFP.

We use Conference Board's Total Economy Database (TED) for internationally comparable time series. While TED covers most of the OECD member countries, there are many missing observations. For this reason, subject to data availability, we sample some of the OECD member countries. To ensure enough number of internationally comparable observations, we focus on highly advanced economies that achieved their industrialization prior to joining the OECD. In this regard, our sample dataset covers 18 OECD developed countries for the period of 1990-2016.

TED notes that TFP captures the contribution of technological advance, efficiency improvements, innovation and other inputs that are not able to be measured directly. A measure of Labor Quantity indicates the level of employment and is based on total hours worked and/or total number of people engaged in the production process. Workers' education level is used to identify productivity differentials across workers and empirically explains the patterns of wages (Bosler et al. 2016). Therefore, Labor Quality is measured by data on 
employment and wages by workers' educational attainments, and its variation shows the changes in the composition of the workforce by education level. Growth in capital stock refers to an increase in the flow of productive capital goods such as buildings, machines, and various equipment including transportation devices. Especially, in TED's classification, ICT capital assets are composed of computer hardware, computer software, telecommunication equipment, and other related services. So, the variables ICT and Non-ICT capture the growth of ICT and non-ICT capital assets, respectively.

Table 1, panel A presents descriptive statistics of variables for the 18 OECD sample countries. The average annual growth rate of potential output for sample countries is 1.47 percent for the period of 1990-2016. The average annual growth of trend TFP is 0.29 percent. Long-run growth rates of Labor Quantity and Labor Quality are 0.53 percent and 0.36 percent, respectively. The average annual growth rate of trend ICT capital is 8.4 percent while trend Non-ICT capital grows at 2.38 percent per year.

In table 1 , panels $\mathrm{B}$ through $\mathrm{D}$ present summary statistics of the variables for sub-sample country groups characterized by region and their economic conditions: G-7, Nordic, and SOE (small open economies). In our classification, G-7 countries are the most advanced economies including Canada, France, Germany, Italy, Japan, the United Kingdom, and the United States. Nordic includes Denmark, Finland, Norway, and Sweden, while SOEs are Australia, Austria, Belgium, Ireland, Netherlands, New Zealand, and Switzerland. SOE is defined as an economy that actively participates in international trade of goods and services and international financial transactions, but due to its small size, its economic activities and policies do not significantly affect the world prices or interest rates. While some papers classify the four Nordic countries as SOEs, this paper separates these four countries from SOEs based on their unique socio-politico and politico-economic aspects. Besides geographical and cultural proximity in the area, in terms of industrial structure, Nordic economies are highly dependent on natural resource extraction. In addition, the four Nordic countries have a large public sector, and they are regarded as role models for active involvement of governance in many areas, such as equality, education, sustainability and various public policies. As a result, compared to other developed countries, they have high welfare spending, a solid public education system, and a 
Table 1. Descriptive Statistics

\begin{tabular}{l|c|c|c|c|c}
\hline \hline \multicolumn{7}{c}{ Panel A: 18 OECD Countries } \\
\hline \multicolumn{1}{c}{ Variable } & Obs. & Mean & Std. Dev. & Min & Max \\
\hline Potential GDP & 486 & 1.468006 & 1.184581 & -1.3 & 6.7 \\
\hline TFP & 486 & .283677 & .7968952 & -1.97131 & 3.05745 \\
\hline Labor Quantity & 486 & .5279353 & .9482684 & -5.21595 & 3.28051 \\
\hline Labor Quality & 486 & .3623993 & .2555269 & -.519729 & 1.05744 \\
\hline ICT Capital & 486 & 8.407187 & 4.529039 & .240633 & 20.1133 \\
\hline Non-ICT Capital & 486 & 2.37688 & 1.334573 & -.393846 & 11.8776 \\
\hline
\end{tabular}

Panel B: G-7 Countries

\begin{tabular}{l|c|c|c|c|c}
\hline \multicolumn{1}{c|}{ Variable } & Obs. & Mean & Std. Dev. & Min & Max \\
\hline Potential GDP & 189 & 1.163492 & .8266122 & -1.3 & 2.7 \\
\hline TFP & 189 & .0995475 & .5839141 & -1.97131 & 1.2152 \\
\hline Labor Quantity & 189 & .2430727 & .763419 & -2.30557 & 1.84245 \\
\hline Labor Quality & 189 & .4641139 & .2316072 & -.303983 & 1.05744 \\
\hline ICT Capital & 189 & 6.942025 & 4.127198 & .240633 & 16.6364 \\
\hline Non-ICT Capital & 189 & 2.30558 & 1.489676 & -.393846 & 11.8776 \\
\hline
\end{tabular}

\section{Panel C: Nordic Countries}

\begin{tabular}{l|c|c|c|c|c}
\hline \multicolumn{1}{c|}{ Variable } & Obs. & Mean & Std. Dev. & Min & Max \\
\hline Potential GDP & 108 & 1.415284 & 1.102969 & -.4 & 3.7 \\
\hline TFP & 108 & .5053146 & 1.046017 & -1.39824 & 2.98754 \\
\hline Labor Quantity & 108 & .2798032 & 1.08767 & -5.21595 & 1.64763 \\
\hline Labor Quality & 108 & .1973621 & .1899026 & -.23937 & .542274 \\
\hline ICT Capital & 108 & 8.541701 & 4.836112 & .373616 & 20.1133 \\
\hline Non-ICT Capital & 108 & 1.984585 & .6786219 & .484674 & 3.37414 \\
\hline
\end{tabular}

\section{Panel D: Small Open Economies}

\begin{tabular}{l|c|c|c|c|c}
\hline \multicolumn{1}{c|}{ Variable } & Obs. & Mean & Std. Dev. & Min & Max \\
\hline Potential GDP & 189 & 1.802646 & 1.427221 & -.1 & 6.7 \\
\hline TFP & 189 & .3411566 & .7803567 & -1.33996 & 3.05745 \\
\hline Labor Quantity & 189 & .9545876 & .8739011 & -1.06449 & 3.28051 \\
\hline Labor Quality & 189 & .3549917 & .2611025 & -.519729 & .917569 \\
\hline ICT Capital & 189 & 9.795482 & 4.297205 & 1.58788 & 17.1714 \\
\hline Non-ICT Capital & 189 & 2.672347 & 1.390068 & -.194311 & 7.41952 \\
\hline
\end{tabular}


lower degree of wage inequality. These factors are identified as key resources for economic prosperity and high quality of life (Tiemer, 2018). Therefore, it is worth estimating the contribution of each determinant to potential GDP growth in these welfare states.

The average potential GDP growth of G-7 countries (1.16 percent) is lower than the average of the whole sample (1.47 percent), and that of SOEs (1.8 percent) is higher than the two other country groups. The average annual growth of trend TFP is highest in Nordic countries ( 0.51 percent) and lowest in G-7 countries ( 0.10 percent). The average annual growth of trend Labor Quality is highest in G-7 countries ( 0.46 percent), while the average annual growth of trend Labor Quantity is highest in SOEs (0.95 percent). The average annual growth rate of trend ICT is highest in the order of SOEs (9.78 percent), Nordic (8.54 percent), and G-7 countries (6.94 percent). The average annual growth of Non-ICT capital stock of SOEs is 2.67 percent, which is higher than that of G-7 countries (2.3 percent) and Nordic countries (1.98 percent). Overall, compared to G-7 countries, Nordic countries and SOEs exhibit higher average growth rates of TFP, Labor Quantity, ICT and Non-ICT.

With respect to trend TFP growth, noticeable differences can be explained by the convergence of productivity among countries. There has been substantial literature on determinants that may affect the productivity convergence, such as R\&D, innovation, knowledge transfer (Cameron, Proudman, and Redding 2005), corporate taxes (Gemmell et al. 2018), public policies, institutions (McMillan and Rodrik 2011), and human resources (Ding, Guariglia, and Harris 2016). In addition, Porter and Van der Linde (1995) suggest that environment regulations may have a positive impact on innovation and productivity growth through the realization of energy efficiency, investment in new technology, and the reduction of production cost. SOEs' high Labor Quantity growth can be attributed to the impact of an increase in labor mobility among EU member countries and immigration rather than an increase in population.

\section{EMPIRICAL RESULTS}

Table 2 and 3 highlight empirical findings that are directly related to our research questions. The empirical results imply that in developed countries, if all factors of production increase at an 
Table 2. Results of Panel Data Regressions

\begin{tabular}{l|c|c|c|c}
\hline \hline & $(1)$ & $(2)$ & $(3)$ & $(4)$ \\
& Pooled OLS & FD & FE & RE \\
\hline TFP & $1.0964^{* * *}$ & $1.0345^{* * *}$ & $0.8660^{* * *}$ & $0.9344^{* * *}$ \\
& $(0.0322)$ & $(0.0696)$ & $(0.0909)$ & $(0.0595)$ \\
Labor Quant. & $0.1784^{* * *}$ & $0.2268^{* * *}$ & $0.2702^{* * *}$ & $0.2408^{* * *}$ \\
& $(0.0259)$ & $(0.0743)$ & $(0.0546)$ & $(0.0482)$ \\
Labor Qual. & $0.6872^{* * *}$ & 0.0645 & 0.2722 & $0.4518^{* *}$ \\
& $(0.0790)$ & $(0.2970)$ & $(0.3967)$ & $(0.2391)$ \\
ICT & $0.0409^{* * *}$ & $0.0719^{* * *}$ & $0.0777^{* * *}$ & $0.0665^{* * *}$ \\
& $(0.0053)$ & $(0.0190)$ & $(0.0174)$ & $(0.0137)$ \\
Non-ICT & $0.3211^{* * *}$ & $0.2525^{* * *}$ & 0.1343 & $0.1886^{* * *}$ \\
& $(0.0186)$ & $(0.0635)$ & $(0.1096)$ & $(0.0649)$ \\
\hline Year FE & No & No & No & No \\
Country FE & No & No & Yes & Yes \\
\hline Adj. $R^{2}$ & 0.8057 & 0.5787 & 0.7947 & 0.7824 \\
Observation & 486 & 468 & 486 & 486 \\
\hline${ }^{*} p<0.10,{ }^{* *} p<0.05,{ }^{* * *} p<0.01$. Robust standard errors in parentheses and \\
the significance of independent variables' coefficients are based on one-tailed \\
tests. Country-fixed effect dummies and year-fixed effect dummies are tested \\
but not reported. We do not report a constant term for parsimony. For FD \\
estimator, we use the first difference values for both dependent and independent \\
variables. For the FE, we report within $R^{2}$, and for the RE, we report between \\
$R^{2}$.
\end{tabular}

equal rate, improvements in productivity and labor quality have the largest impact on potential output growth. G-7 countries have large domestic markets and well-developed industries. Thus, the contributions of TFP, both Labor Quantity and Quality, and Non-ICT capital to potential GDP are greater in G-7 countries than the two other country groups. In Nordic countries, the coefficient of Labor Quality is larger than other significant determinants, TFP, Labor Quantity, and ICT. This implies that in these countries, education and other investments in human capital significantly affect the promotion of economic potential. Like other two country groups, in SOEs, the impacts of TFP and Labor Quality are larger than other determinants. Given that SOEs lack economy of scale due to small domestic markets, a negative contribution of traditional capital stock in SOEs is not surprising. The regression results suggest that SOEs' potential GDP growth is more highly dependent on investments 
in ICT, compared to other country groups. This might indicate changes in industrial structure in SOEs. Empirical results show that ICT capital is more influential in SOEs than in G7 countries. We attribute this result to differences in industrial structures between SOEs and G7 countries. Compared to the seven SOEs in our sample, in G7 countries, non-ICT intensive industries constitute a larger proportion of their economies. For example, Eicher and Strobel (2008) report that non-ICT capital deepening is about three times greater than ICT capital deepening in Germany. Since nonICT capital deepening serves as a significant driver of GDP growth in the highly advanced G7 economies, the relative importance of ICT capital can be smaller in G7 countries than in SOEs.

Table 2 and 3 present two sets of regression results. In table 2, we estimate the model using four estimators: pooled (panel)OLS, First Difference (FD), Fixed Effect (FE), and Random Effect (RE). In each estimation, we use roust standard errors to control heteroskedasticity and autocorrelation. Year-specific effects may exist across the sample, implying various global shocks at specific year(s). We can also consider the existence of idiosyncratic countryspecific shocks. Panel data specific estimators, the FE and RE, control for these time-invariant country-fixed effects, while the OLS and FD estimators assume that there are no such effects in the panel dataset. However, all of the four baseline regressions do not control year fixed effects.

As expected, the effect of improvement of productivity is positive and uniformly significant across estimations in columns (1) through (4) in table 2. Similarly, the positive Labor Quantity coefficients are uniformly significant and suggest that potential workforce growth is significantly correlated with economic potential. Labor Quality is positively associated with potential GDP growth, but significant only in the OLS and RE estimations. ICT coefficients are positive and consistently significant in all four estimations. NonICT yields a positive coefficient, but significant in the OLS, FD, and RE estimations only. Specifically, a 1 percent increase in trend TFP contributes to potential GDP growth in a range of 0.87 percent to 1.10 percent. A 1 percent increase in the long-run growth of Labor Quantity contributes to potential GDP growth by $0.18-0.27$ percent. In the OLS, a 1 percent increase in the long-run growth of Labor Quantity contributes to potential GDP by 0.69 percent, and it goes down to 0.45 percent in $\mathrm{RE}$ estimation. A 1 percent growth of 
Table 3. Results of Fixed Effects Models

\begin{tabular}{l|c|c|c|c}
\hline \hline & $(1)$ & $(2)$ & $(3)$ & $(4)$ \\
& OECD 18 & G-7 & Nordic & SOE \\
\hline TFP & $0.8421^{* * *}$ & $1.3004^{* * *}$ & $0.6257^{* * *}$ & $0.9539^{* * *}$ \\
& $(0.0431)$ & $(0.0833)$ & $(0.0472)$ & $(0.0633)$ \\
Labor Quant. & $0.2559^{* * *}$ & $0.4539^{* * *}$ & $0.3888^{* * * *}$ & $0.2820^{* * *}$ \\
& $(0.0364)$ & $(0.0636)$ & $(0.0647)$ & $(0.0503)$ \\
Labor Qual. & $0.2954^{* *}$ & $2.2188^{* * *}$ & $1.2268^{* * *}$ & $0.4016^{* *}$ \\
& $(0.1278)$ & $(0.2146)$ & $(0.3996)$ & $(0.1752)$ \\
ICT & $0.0859^{* * *}$ & $0.0857^{* * *}$ & $0.0466^{* * *}$ & $0.1964^{* * *}$ \\
& $(0.0157)$ & $(0.0152)$ & $(0.0169)$ & $(0.0209)$ \\
Non-ICT & $0.1616^{* * *}$ & $0.2857^{* * *}$ & 0.1201 & $-0.1903^{* * * *}$ \\
& $(0.0348)$ & $(0.0214)$ & $(0.1465)$ & $(0.0609)$ \\
\hline Year FE & Yes & Yes & Yes & Yes \\
Country FE & Yes & Yes & Yes & Yes \\
\hline Adj. $R^{2}$ & 0.8897 & 0.8991 & 0.9692 & 0.9327 \\
Observation & 486 & 189 & 108 & 189 \\
\hline
\end{tabular}

${ }^{*} p<0.10,{ }^{* *} p<0.05,{ }^{* * *} p<0.01$. Robust standard errors in parentheses and the significance of independent variables' coefficients are based on one-tailed tests. Country-fixed effect dummies and year-fixed effect dummies are tested but not reported. We do not report a constant term for parsimony.

trend Non-ICT capital can lead to potential GDP growth of $0.19-0.32$ percent, while an equal increase in trend ICT capital causes 0.05 0.78 percent increase in potential GDP.

To find a preferred estimator, we apply a battery of statistical tests. Breusch and Pagan Lagrangian multiplier (LM) test suggests the RE estimation over the OLS and the FD estimations, with the test statistic $\bar{\chi}^{2}(01)=216.33$. The $F$-test to test for whether fixed effects are jointly zero suggests that the $\mathrm{FE}$ estimation is preferred over the OLS and FD estimations, with test statistic $F(17,463)=$ 14.15. Finally, the robust version of the Hausman test suggests that FE estimation over the RE estimation, with the Hansen test statistic of 19.32 .

Based on these results, next we apply the FE estimator to the sample data. To control both country-specific and year-specific fixed effects, we include dummy variables in our empirical model. Table 3 presents the results of the two dimensional-fixed effect 
panel data regressions for each country group, making it possible to compare the role of each determinant by the different economic characteristics.

In column (1), on average across 18 OECD countries, a 1 percent increase in the trend TFP is associated with a 0.84 percent increase in the potential GDP. Similarly, a 1 percent increase in the trend Labor Quantity, Labor Quality, ICT, and non-ICT increase potential GDP by a 0.26, 0.30, 0.09, and 0.16 percent, respectively. Columns (2) through (4) in table 3 exhibit empirical results for the three country groups. As shown in column (2), in G-7 countries, a 1 percent growth of trend TFP increases potential GDP by a 1.3 percent, which is higher than the 18 OECD average ( 0.84 percent). This coefficient value goes down to a 0.95 in SOEs and a 0.63 percent in Nordic countries. The coefficient of trend Labor Quantity is highest in G-7 countries, with the coefficient of 0.45 , while lowest in SOEs at 0.28. Similarly, the contribution of long-run Labor Quality is also highest in G-7 countries, with the coefficient of 2.22, which is about five times greater than the coefficient of 0.40 in SOEs. In all three country groups, the long-run growth of ICT capital stock positively affects economic potential. Especially, its influence is highest in SOEs, with the coefficient of 0.19 , which is higher than the coefficient of 0.09 in G-7 countries and 0.05 in Nordic countries. The impact of long-run growth of Non-ICT capital is positive with the coefficient of 0.29 and significant in G-7 countries, but flips the sign and gives -0.19 in SOEs. In Nordic countries, the coefficient of NonICT is positive, but not significant.

\section{CONCLUSION}

A nation's wealth is determined by its production activities. The availability of sufficient good-quality labor force and capital assets is a necessary condition for competitive industrial performance and sustains higher growth of output. In addition, an increase in productivity helps more efficient utilization of those factors of production. Therefore, continuous enhancement of the quality of production system becomes a ground for national competitiveness and furthermore, a fundamental component of sustainable prosperity.

This paper provides an empirical analysis on the structural 
relationship between production inputs and outputs in developed economies. Empirical evidence suggests that in developed countries, since 1990, productivity and the quality of labor force have significantly affected the potential rate of output growth. Regression results also show that the effects of investments in ICT industries have been particularly large in small open economies, and non-ICT capital assets are still major determinants in G-7 economies.

Technological progress and innovation replace the traditional role of labor input, reduce work hours and the level of employment, and thereby emphasizing the importance of the quality of workforce. Hence, adopting automation in production process can lower production costs and realize the effects of scale expansion. If a decrease in demand for labor continues, the quality of labor determined by workers' education attainments will shape the growth of economic potential. The more the industry is characterized by innovative technologies, the more such an industry demands labor quality over labor quantity. Decline of a labor force due to population decrease and reduced work hours will lower the contribution of labor quantity. As a result, a better access to higher education and the provision of effective on-site job trainings may help reinforce the competitiveness of the economic system. Implementing public policies that foster opportunities for improving skills and knowledge will make workforce more competent. Industrial restructuring performed by both the public and private sectors promoting the effective use of input resources can harden production environment.

Structural time series modeling and filtering techniques used in this paper provide estimates of stochastic long-run growth of output. These methods are applicable to estimate other unobservable variables discussed in the fields of business and economics, such as price stability and stock return trends.

Applying an analysis similar to that used in this paper to other heterogeneous groups of countries, such as emerging market economies, will also be interesting and help a more comprehensive understanding of the nature of potential output growth.

\section{APPENDIX}

A state-space model requires two equations, a measurement equation and transition equation, which show the relationship 
between observable and unobservable components and the dynamic changes in the unobservable variables, respectively. A matrix form of measurement equation is given by,

$$
y_{t}=\left[\begin{array}{llll}
1 & 1 & 0 & 0
\end{array}\right]\left[\begin{array}{c}
\tau_{t} \\
c_{t} \\
c_{t-1} \\
\beta_{t}
\end{array}\right]
$$

The above equation shows a linear combination of the potential output and cyclical component. A matrix form of the transition equation is given by,

$$
\left[\begin{array}{c}
\tau_{t} \\
c_{t} \\
c_{t-1} \\
\beta_{t}
\end{array}\right]=\left[\begin{array}{cccc}
1 & 0 & 0 & 1 \\
0 & \phi_{1} & \phi_{2} & 0 \\
0 & 1 & 0 & 0 \\
0 & 0 & 0 & 1
\end{array}\right]\left[\begin{array}{c}
\tau_{t-1} \\
c_{t-1} \\
c_{t-2} \\
\beta_{t-1}
\end{array}\right]+\left[\begin{array}{c}
v_{t} \\
\varepsilon_{t} \\
0 \\
\omega_{t}
\end{array}\right]
$$

The Kalman filter provides the smoothed series of $\tau_{t}$ and $\beta_{t}$ and the optimal estimates of the parameters, $\sigma_{v}^{2}, \sigma_{\omega}^{2}$, and $\sigma_{\varepsilon}^{2}$ that maximize the following likelihood function,

$$
\ln L=-\frac{1}{2} \sum_{t=1}^{T} \ln \left(2 \pi^{n} \operatorname{det}\left(f_{t \mid t-1}\right)\right)-\frac{1}{2} \sum_{t=1}^{T} \eta_{t \mid t-1}^{\prime} f_{t \mid t-1}^{-1} \eta_{t \mid t-1}
$$

where $T, f_{t \mid t-1}$, and $\eta_{t \mid t-1}$ denote the sample size, the prediction errors defined by $y_{t}-y_{t-1}$ and the variance of the prediction errors, respectively.

\section{REFERRENCES}

Aghion, P. and P. Howitt (1998), "Endogenous Growth Theory," Cambridge, MA, USA: MIT Press.

Audretsch, D. B. and M. Keilbach (2004), "Does Entrepreneurship Capital Matter?" Entrepreneurship Theory and Practice, 28(5), 419-430.

Bosler, C., M. C. Daly, J. G. Fernald, and B. Hobijn (2016), "The Outlook for US Labor-Quality Growth," National Bureau of Economic Research.

Cameron, G., J. Proudman, and S. Redding (2005), "Technological Convergence, R\&D, Trade and Productivity Growth," European 
Economic Review, 49(3), 775-807.

Clark, P. K. (1987), "The Cyclical Component of US Economic Activity," The Quarterly Journal of Economics, 102(4), 797-814.

(1989), "Trend Reversion in Real Output and Unemployment," Journal of Econometrics, 40(1), 15-32.

Coe, D. T. and E. Helpman (1995), "International R\&D Spillovers," European Economic Review, 39(5), 859-887.

Coe, D. T., E. Helpman, and A. W. Hoffmaister (2009), "International R\&D Spillovers and Institutions," European Economic Review, 53(7), 723741.

Delgado, M., C. Ketels, M. E. Porter, and S. Stern (2012), "The Determinants of National Competitiveness," National Bureau of Economic Research.

Ding, S., A. Guariglia, and R. Harris (2016), "The Determinants of Productivity in Chinese Large and Medium-Sized Industrial Firms, 1998-2007," Journal of Productivity Analysis, 45(2), 131-155.

Eicher, T. S. and T. Strobel (2008), "Germany's Continued Productivity Slump: An Industry Analysis," Ifo Working Paper.

Gemmell, N., R. Kneller, D. McGowan, I. Sanz, and J. F. Sanz-Sanz (2018), "Corporate Taxation and Productivity Catch-Up: Evidence from European Firms," The Scandinavian Journal of Economics, 120(2), 372-399.

Gennaioli, N., R. La Porta, F. Lopez-de-Silanes, and A. Shleifer (2012), "Human Capital and Regional Development," The Quarterly Journal of Economics, 128(1), 105-164.

Gerlach, H. M. S. and F. Smets (1997), "Output Gaps and Inflation: Unobservable-Components Estimates for the G-7 Countries," Bank for International Settlements.

Goldin, C. D. and L. F. Katz (2009), The Race between Education and Technology, Cambridge, MA, USA: Harvard University Press.

Griliches, Z. (1998), Productivity, R\&D, and the Data Constraint. In R\&D and Productivity: The Econometric Evidence, University of Chicago Press. 347-374.

Griliches, Z. and J. Mairesse (1984), Productivity and R\&D at the Firm Level. In R\&D, Patents, and Productivity, University of Chicago Press, 339-374.

Guellec, D. and B. Van Pottelsberghe de la Potterie (2004), "From R\&D to Productivity Growth: Do the Institutional Settings and the Source of Funds of R\&D Matter?" Oxford Bulletin of Economics and Statistics, 66(3), 353-378.

Harvey, A. C. (1991), Forecasting, Structural Time Series Models and the Kalman Filter, Cambridge, England: Cambridge University Press. (2001), "Testing in Unobserved Components Models," Journal of Forecasting, 20(1), 1-19.

Harvey, A. C., S. J. Koopman, and N. Shephard (2004), State Space and 
Unobserved Component Models: Theory and Applications, Cambridge, England: Cambridge University Press.

Harvey, A. C. and M. Streibel (1998), "Testing for Nonstationary Unobserved Components," Journal of Time Series Analysis, 19(5), 505-529.

Harvey, A. C. and J. Bernstein (2003), "Measurement and Testing of Inequality from Time Series of Deciles with an Application to US Wages," Review of Economics and Statistics, 85(1), 141v152.

Jones, C. I. (1995), "R\&D-Based Models of Economic Growth," Journal of Political Economy, 103(4), 759-784.

Krueger, A. B. and M. Lindahl (2001), "Education for Growth: Why and for Whom?” Journal of Economic Literature, 39(4), 1101-1136.

Lucas Jr, R. E. (1988), "On the Mechanics of Economic Development," Journal of Monetary Economics, 22(1), 3-42.

McMillan, M. S. and D. Rodrik (2011), "Globalization, Structural Change and Productivity Growth," National Bureau of Economic Research.

Michelacci, C. (2003), "Low Returns in R\&D due to the Lack of Entrepreneurial Skills," The Economic Journal, 113(484), 207-225.

Perron, P. and T. Wada (2009), "Let's Take a Break: Trends and Cycles in US Real GDP," Journal of Monetary Economics, 56(6), 749-765.

Porter, M. E. (1990), The Competive Advantage of Nations, New York, USA: Free Press.

Porter, M. E., C. Ketels, and M. Delgado (2007), "The Microeconomic Foundations of Prosperity: Findings from the Business Competitiveness Index," The Global Competitiveness Report 2007-2008, 51-81.

Porter, M. E. and C. Van der Linde (1995), "Toward a New Conception of the Environment-Competitiveness Relationship," Journal of Economic Perspectives, 9(4), 97-118.

Romer, P. M. (1990), "Endogenous Technological Change," Journal of Political Economy, 98(5, Part 2), S71-S102.

(1994), "The Origins of Endogenous Growth," Journal of Economic Perspectives, 8(1), 3-22.

Solow, R. M. (1957), "Technical Change and the Aggregate Production Function," The Review of Economics and Statistics, 39(3), 312-320.

Swan, T. W. (1956), "Economic Growth and Capital Accumulation," Economic Record, 32(2), 334-361.

Tiemer, J. (2018), "The Success of the Nordic Countries as a Blueprint for Small Open Economies," Intereconomics, 53(4), 209-214.

Vandenbussche, J., P. Aghion, and C. Meghir (2006), "Growth, Distance to Frontier and Composition of Human Capital," Journal of Economic Growth, 11(2), 97-127.

Watson, M. W. (1986), "Univariate Detrending Methods with Stochastic Trends," Journal of Monetary Economics, 18, 49-75. 
Received November 7, 2018 Revised January 7, 2019 Accepted January 27, 2019 